\title{
Impact of Microfinance Institutions on Economic Empowerment of Women Entrepreneurs in Developing Countries
}

\author{
Fwamba Rashid, Matete John, Nasimiyu Consolatta, Sungwacha Stephen \\ Kibabii University College, Bungoma, Kenya \\ Email: rfwamba@kibabiiuniversity.ac.ke
}

\begin{abstract}
This study mirrored out the effects of Microfinance on economic empowerment of Women Entrepreneurs in developing economies. Descriptive research design was used to assess the extent to which Women economic empowerment co-relates with Microfinance Institutions services. The target population was women entrepreneurs in Micro Finance Institutions (MFIs) within Kakamega C.B.D. Simple random probability sampling was applied to select ten (10) MFIs where four (4) active women entrepreneurs from each MFI was taken, adding to forty (40) respondents. Both primary and secondary data was collected through questionnaires and semi-structured interviews. Data collected was presented by descriptive statistics like pie charts and graphs. From the analysis, the results showed that microfinance services act as a key fulcrum to women entrepreneurs' economic empowerment. The results were reaffirmed by a linear regression analysis (SPSS version 22). The findings will be used to make policy proposals that will see MFIs meet the economic empowerment needs of women Entrepreneurs to make developing countries progress as Kenya prepares to achieve vision 2030.
\end{abstract}

Keywords: Economic empowerment, Entrepreneurship, Developing economies and entrepreneurship, Kenya

\section{Introduction}

Various studies have been carried out on the impact of Micro Finance Institutions (MFIs) on economy. At one extreme end are studies arguing that MFIs have a very beneficial impact to the women entrepreneurs in terms of economic empowerment (Holcombe, 2005 and Hossain, 2008.). At the other end is few writers who caution against such optimism and point out to the negative impacts that MFIs have on economic women empowerment i.e. MFIs are not silver bullets (Adams and von Pischke, 2009 and Buckley, 2007). In the 'middle' is the work that identifies beneficial impacts but argues that microfinance does not assist/empower the women economically, as is so often claimed (Hulme and Mosley, 2006; Mosley and Hulme, 2008). Given this state of affairs the assessment of microfinance programs' effects on economic empowerment on Entrepreneurs remains an important field for researchers, policymakers and development practitioners. (Gupta, 2005).

The interest in microfinance has burgeoned during the last two decades: multilateral lending agencies, bilateral donor agencies, developing and developed country governments, and nongovernment organizations (NGOs) support the development of microfinance provisions to women (World Bank, 2006). A variety of private banking institutions has also joined this group in recent years. As a result, microfinance services to women have grown rapidly during the last decade, although from an initial low level, and have come to the forefront of development discussions concerning economic empowerment of women (Yunus, 2008). 
Mohamed Yunus (2007), in his Asian Development Bank evaluation on impact of women Entrepreneurs' economic empowerment, found out that the five microfinance projects that were under study supported the importance of considering women entrepreneurship in all aspects of microfinance projects.

Despite mixed results overall, the evaluation found that the projects had positive effects on women economic empowerment. In particular it found that women entrepreneurs had: A greater role in domestic household generation of cash, Greater involvement in major expenditure decisions and generating cash savings, Ability to generate more income on their own and greater role in business decisions, Acquisition of more skills and expanding their network of friends and support system and Increased acquisition of assets.

Besides, the empirical evidence emerging from various studies on the effect of microfinance on women economic empowerment in developing economies performance have so far yielded mixed results that are inconclusive and contradictory (Trachim,2006). Thus, the question on whether microfinance improves or worsens economic empowerment and performance of developing economies is still worth of further research. In addition, the impact of microfinance on entrepreneurial development has not received adequate research attention in East Africa (C.B.K, 2008). Recent Research done on East Africa's Women entrepreneurs' economic empowerment, World Bank (2008), shows only the positive impacts of microfinance in terms of microcredit only on women economic empowerment in East Africa and the rest of developing economies.

As an industry, micro finance is a relatively new phenomenon in Kenya, with a few agencies starting about 20 or so years ago but the sector gained the status of an industry only in the last 10 years (UNDP, 2009). Despite the enactment of the Microfinance Act (2006) and the rapid growth of Microfinance, of about 40 commercial banks and hundreds of SACCOs, $35.2 \%$ of Kenyan Women are still in need of financial services partly because of their inability to access the formal financial services), and another $30.2 \%$ are entirely excluded from accessing any financial services ( C.B.K,2007) .

The Government of Kenya (G.O.K) has indirectly provided a boost to the micro-finance sector. By virtue of illuminating on vision 2030, the G.O.K has been implementing a Structural Adjustment Program, which has resulted in the liberalization of the economy. This has given due consideration to efforts and programs directed at the economic empowerment of women through the formation of organizations such as Maendeleo Ya Wanawake and Kenya Women Finance Bank (Kenya bureau of statistics, 2008). However, not all seems to be well especially to the women entrepreneurs' economic empowerment (UNDP, 2009).

Lack of access to credit was considered a major bottleneck for women entrepreneurial development according to a report released by the Central Bank of Kenya in 2008.However when Micro Finance (in particular the client based ones) sought financial support from the International donor community, the response by the donor community has been generous and since then these MFIs have in terms of their source of funding become donor-oriented.

A conservative estimate indicates that the Micro-Finance industry has received a total of US Dollars 80 Million to date from the donor community. While Government and Non-Government Organizations (NGOs) have been putting in place a number of programmes and policies to promote women economic empowerment in developing economies, Kenya is still listed among the poorest countries in the world with a high level of women Entrepreneurs uneconomically empowered mainly characterized by unemployment, low savings, limited access to borrowings and no control of resources. At the same time the few women empowered do not have sufficient knowledge about how to go about after achieving economic empowerment (WEFP, 2008).

Although Women entrepreneurs have been subscribing to MFIs in the past one decade with the main aim of becoming economically empowered, little has turned positive to them (Rogally,2009). This reality suggests that there might be a problem with either the MFIs or their clients. Women entrepreneurs in developing countries are not economically empowered by MFIs. Although huge amounts of money have been spent by various developing countries' governments and non-Government Organizations investing on this platform through MFIs over the years, they seem not to yield any meaningful result (Rogally, 2002). Poverty is still a characteristic of women entrepreneurs who depend on MFIs in developing countries (Copestake, 2007). 
The effect of low economic empowerment amongst women entrepreneurs is so extreme in developing economies to an extent that Central Business Districts of major cities in developing economies experience slow growth due to low economic empowerment of women entrepreneurs despite them subscribing to MFIs.A case in point is the Nairobi Central Business District in Kenya as revealed in the World Bank report of 2008. Most related studies have dealt much on the Microcredit as a sole MFI service with some positing that MFIs services have positive effect, others positing on negative effects while some positing on the moderate effects of MFIs on women economic empowerment, others post that there is more to economically empower the Women entrepreneurs by Microfinance Institutions than just Microcredit (Carter 2006 and Shaw, 2001). There are other services like advisory, insurance, savings, asset financing and that women entrepreneurs can be given by the MFIs to help them achieve economic empowerment ( Gupta,2005).

This explains the growing interest of researchers, NGOs and politicians in women entrepreneurs' economic empowerment through MFIs, and the major concern is to find efficient means for promoting women who are considering getting economic empowerment through entrepreneurship with the financial support from MFIs. This study empirically analyses all this effects from different kinds of MFIs in Kenya through assessment of their (MFIs) impact on economic empowerment of women Entrepreneurs in developing economies by undertaking an insight analysis of Nairobi County's Nairobi town CBD.

The general objective of this study is to assess the extent to which MFIs services have affected the economic empowerment of women Entrepreneurs in developing countries.

The specific objectives of this research were to:

1. Examine the impact of Microfinance services on women Entrepreneurs' self-employment ability.

2. Determine the impact of Microfinance services on women Entrepreneurs' rate of control of resources).

3. Establish the impact of Microfinance services on Women Entrepreneurs' savings level.

4. Evaluate the impact of Microfinance services on Women Entrepreneurs' access to credit facilities.

\section{Literature Review}

\subsection{Entrepreneurship Theory}

This involved a collection of interrelated theories existing with a view to explain Microfinance services that influence various economic empowerment parameters of women entrepreneurs. This theoretical framework was as given by different scholars aiming at determining how microfinance affects various economic empowerment levels of women entrepreneurs.

This research is underpinned on the Entrepreneurship Theory of Shane (2003). The theory consists of opportunity discovery, evaluation of the opportunity and the decision to exploit the opportunity. Other elements of the theory include self-employment, business operation and economic empowerment. The theory highlighted four operational measures of performance which are survival, economic growth, profitability/income, and experiencing initial public offering. Survival refers to continuation of entrepreneurial activity while growth refers to increase in the venture's sales and employment. Profitability refers to a new surplus of revenue over cost while experiencing initial public offer refers to the sale of stock to the public (Shane, 2003). Opportunities are created by the institutional or external environment for those entrepreneurs who could identify them to start or improve their businesses and subsequently, their welfare (North, 1990; Shane, 2003).

Entrepreneurs' ability to identify and tap such opportunities differs between entrepreneurs. It also depends on their ability to access information and willingness to act upon the information in terms of risk; that is their attitude (Shane, 2003). Individual attributes affect discovery of entrepreneurial opportunity. It is made up of psychological and demographic factors such as motives, attitude to risk, education and training, career experience, age and social status.

Changes in business environment such as economic, financial, political, legal, and socio-cultural factors also affect discovery of opportunity. For example, income level of the entrepreneur, capital availability, political stability, laws concerning private enterprise and property rights, and desire for enhanced social status by the entrepreneur could affect discovery of entrepreneurial opportunity. Type of industry also affect opportunity discovery. Industrial sectors such as distribution, manufacturing, agriculture, catering, and business services are more attractive to entrepreneurs (Brana, 2008; Carter \& Shaw, 2006; Gatewood et al., 2004; Riding, 2006; Shane, 2003; Stohmeyer, 2007). The concentration 
of industries in a particular location could also influence discovery of entrepreneurial opportunity by those in that location (Shane, 2003). Evaluation of the identified opportunity is another stage in the entrepreneurial process, and appropriate decision at this stage leads to the decision to exploit the opportunity (Shane, 2003). The decision to exploit the opportunity depends on the intention of the entrepreneur, and the appropriate measure of entrepreneurial decisionmaking is intention, which leads to recognition of entrepreneurial opportunities (Shane, 2003).

\subsection{Microfinance effects on control of resources by women entrepreneurs}

A key objective of many microfinance interventions is to empower women economically. Mosedale (2003) in his paper "Institutional determinants of Savings" states that if we want to see women economically empowered, it means we are currently seeing them as being economically disempowered, disadvantaged by the way power relations shape their choices, opportunities and well-being. She states that women empowerment cannot be bestowed by a third party but must be claimed by women seeking empowerment through an ongoing process of reflection, analysis and action (2003).

Littlefield, Murduch and Hashemi (2003) state that access to MFIs can empower women Entrepreneurs economically to become more confident, more assertive, more likely to take part in family and community decisions and better able to confront gender inequities (acquisition of resources/control of resources). However, they also discovered that just because women are clients of MFIs does not mean they will automatically become economically empowered. Hulme and Mosley (1996) also make this point when they refer to the "naivety of the belief that every loan made to a woman contributes to the strengthening of the economic and social position of women". However, with careful planning and design women's position in the household and community can indeed be improved. According to Littlefield, Murduch and Hashemi (2003), the Women's Empowerment Program in Nepal found that $68 \%$ of its members were making decisions on buying and selling property, sending their daughters to school and planning for their families (control over resources), all decisions that hitherto were made by their husbands. They refer to studies in Ghana and Bolivia, which indicated that women entrepreneurs involved in microfinance projects had attained increase in acquisition/ control over resources.

\subsection{Knowledge Gap}

From the review of literature the question as to whether MFIs services have effects on economic empowerment of women entrepreneurs is not tackled in a broader way instead the focus has been on the microcredit as a general MFIs service; furthermore, there are very few literature on negative effects of MFIs services to Women economic empowerment but still with much bias of the microcredit. This study proposes to look at a number of MFIs services and their total effects on women entrepreneurs' economic empowerment.

\subsection{Conceptual framework}

The research study conceptualized out on the effects of Microfinance services as independent variables, on Women Entrepreneurs' economic Empowerment (self-employment, acquisition/ control of resources, increased savings and access to borrowings) as dependent variables as illustrated below. 


\author{
Independent Variables \\ MFIs services
}

\author{
Dependent Variable \\ Economic empowerment variables
}

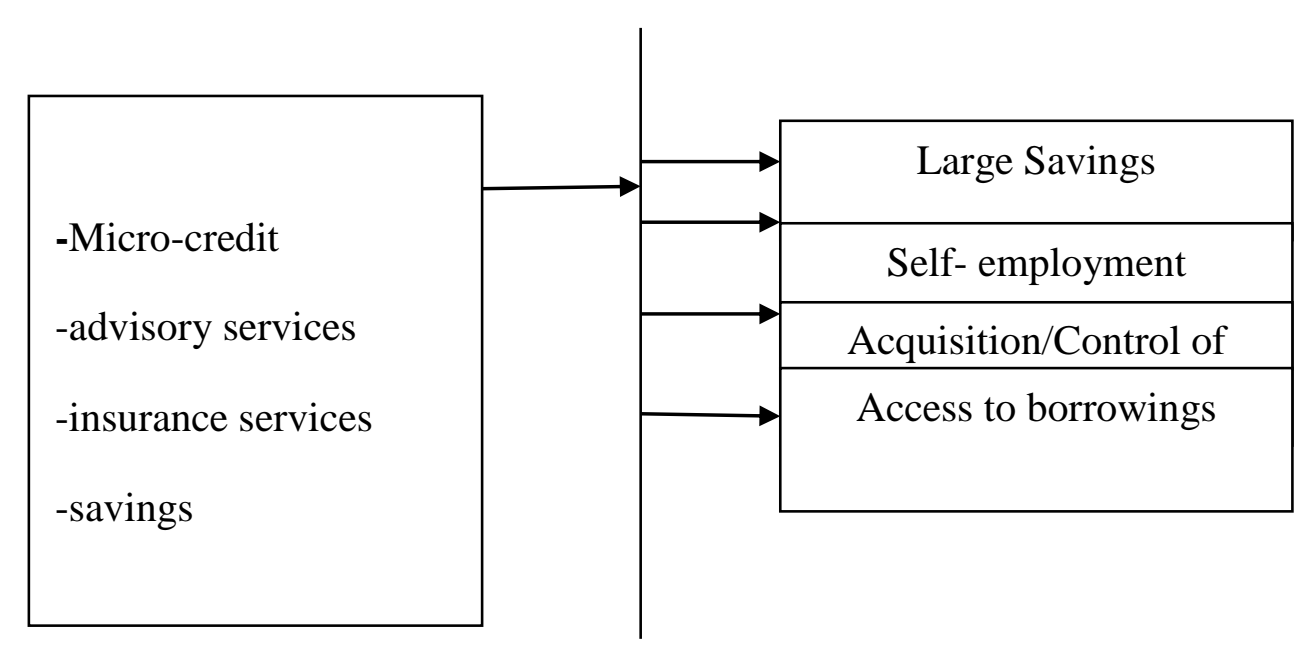

Figure 1: Conceptual framework

Source: Author (2015)

\section{Data and Methodology}

This chapter deals with the mode in which this study will be carried out to evaluate the research questions mentioned in chapter one and two. It gives out the research design that will be applied. It proceeds further to depict the target population of the study with the sampling technique that will be deployed. After which it ponders on the data collection tools and how the collected data will be presented. This chapter winds up by putting forward the analytical tools that will be used to analyze the presented data.

\subsection{Research design}

Malhorta (2004) defines descriptive research as a research design in which the major emphasis is on determining the frequency with which something occurs or the extent to which two variables co-vary. Yunus (2008) involved a crosssectional descriptive research involving the collection of information from his sample of population elements only once in his study on microfinance effects. Because cross-sectional studies are one-time measurements, they are also referred to as "snapshots" of the population. Cross-sectional studies normally employ fairly large sample (Koszak 2007).It is with this reference that this study deployed multiple cross sectional-descriptive design where two or more samples of respondents and information from each sample were obtained i.e. four respondents from the list of most active entrepreneurs were interviewed.

The universe of the study comprised of selected customers of Microfinance institutions in Kenya, (Kakamega C.B.D). It was necessary that the approached respondents were to be clients for Microfinance Institutions. The general and operational Managers of each Microfinance Institutions were approached to provide a list of active women entrepreneurs in a given MFIs. The respondents who did not use these services were to be excluded from the sample. Gupta (2005) deployed a similar approach in the general research of women participation in SMEs.

The research instrument was mailed to identified respondents addresses; others were personally be distributed using drop and pick method. E-mail attachment through the internet was also used to send the questionnaires to known customers. Out of the total forty (40) questionnaires sent to respondents and after several reminders, some 45 responses were received. 


\subsection{Study Population and sample}

Study Population is the perceived or targeted field of the respondents in any given particular research (Mugenda 2006). Kothari, (2004) defines study population as the sum total of elements about which inferences are to be made. Thus, the group made up of all possible observations of a characteristic of interest is the population, while a collection of observations presenting only a portion of that population is a sample (Denscombe, 1998). Kakamega CBD as the base for this study consists of one hundred thousand $(100,000)$ women (bureau of statistics, 2011). The total population of Microfinance institutions (MFIs) of different nature in Kenya is one hundred (100) (C.B.K, 2012). This study employed $10 \%$ of the MFIs' Population i.e. ten (10) MFIs to assist study four (4) selected consistent and active women Entrepreneurs from each MFI(names from the operations officer records) and found out their levels of economic empowerment through questionnaires, observations and interviews. Such methodology was adopted by Mohamed Yunus (2008) in his study on "Microcredit and its positive effects" journal.

Mugenda and Mugenda, (2004) defines cross-sectional research as the carrying out of a study on a representative respondent to give a general conclusion. This research was carried through a cross-sectional survey design which asked respondents on their usage of Microfinance services. The design of the questionnaire was based on a multiple-item measurement scale (Microfinance institutions). It looked into the relationship between microfinance activities and development parameters (poverty alleviation, women empowerment) in the Kenyan Microfinance industry. This study is suitable when dealing with many members in a population where it is not possible to study all of them and hence to call for sampling in order to come up with a generalizations and inferences about the whole population. Similar studies that have successfully used this research design are; Norizan (2005) and Gakuo (2003).

Simple random sampling was used because the population is relatively large and contains a series of the almost same cadre of respondents similar approach was used by Kothari in 2006. Each element in the population had a known and equal probability of selection. This procedure ensured a high degree of equal chances of representation of all in the population. The sample percentage of the MFIs to be researched on was 10\% of different kinds of MFIs in Kakamega CBD as recommended by (Mugenda, 2003) who further notes that a sample of 10\% is representative for relatively large populations .Simple random sampling was employed to get the four active women Entrepreneurs from a group of active women entrepreneurs from each MFI ( $\mathrm{N} / \mathrm{n}=$ interval of sampling, $\mathrm{N}=$ total population of active women Entrepreneurs as per the operations officers records while $n=4$ ). The questionnaires were distributed to the four active women/clients in each MFI selected. The study was not based on specific qualifications of the respondents, but it will cut across all the levels of education. Such a sampling procedure was conducted by Gupta (2005) in his study on elements of microfinance in developing economies.

Ten out of the one hundred categories of the MFIs were selected from the list of Kenya's MFIs in Kakamega C.B.D. The researcher targeted women Entrepreneurs as respondents who were contacted through questionnaires that were mailed or physically distributed.

The sample constituted of $10 \%$ of the targeted MFIs population (100 in number) comprising of customers/Entrepreneurs of Microfinance Institutions studied. This means the study studied ten MFIs of different nature in the country found in Kakamega CBD. The Study however did simple random sampling to obtain four women Entrepreneurs from a list of active women entrepreneurs who were provided by the operational manager/credits officer in each MFI. It adopted the mode $\mathrm{N} / \mathrm{n}$ = sampling interval, where $\mathrm{N}=$ total number of active women entrepreneurs as per records while $\mathrm{n}=4$ the required number of women entrepreneurs to be interviewed as adopted by Kothari (2000).

\subsection{Data collection}

\subsubsection{Data collection methods}

The study used primary data, which was captured through semi-structured questionnaires. The questionnaire consisted of both closed and open-ended questions and had three sections. Section one dealt with general information on the participants. Section two had to seek information on the microfinance services in research questions and if the client or manager was aware of them. Section three was to seek information on the benefits and harmful implications from the services the clients had knowledge over. The questions were presented on a licker scale (agree, strongly agree, disagree and strongly disagree) for respondents to score statements that describe the consumer's perceptions on Microfinance services and their performance in business or financial freedom status. 


\subsubsection{Pre-testing}

The questionnaire was subjected to a pilot test before final administration to the respondents. A random sample of 20 (twenty) women clients from ten(10) selected MFIs representing 10\% of the population were selected from the que ues and given the questionnaire to fill in the presence of the researcher. The choice of twenty respondents for the pilot study was out of a mere need for convenience. The results were used to check for reliability and validity of the instruments that were used. Cronbach's alpha was computed and was higher than 0.7 , thus the instrument was considered as reliable. However it should be noted that there is no rule to suggest that a Cronbach's alpha greater than 0.70 indicates a good instrument (Comer and Kelly 1982). Although, it is commonly agreed among researchers that an alpha greater or equal to 0.7 shows that an instrument is reliable in measuring what it was intended to measure. The pilot test also helped the researcher in clearing any ambiguities and in ensuring that the questions posed measured what it was intended to measure.

\subsection{Data presentation and analysis methods}

Kothari (2007) defines data presentation as the depiction or relaying of collected and summarized information to the end users in a more understandable, simple and accurate form. Data collected in this study was presented using two modes of statistical techniques namely pie charts and bar graphs. To establish the relationship between Microfinance and women economic empowerment in developing economies, frequency and percentage proportions of the statement describing the relationship was used. From the same scores, means were calculated to determine the strength of relationship. Regression analysis was be used to establish the relationship between Microfinance services and the Women economic empowerment. To determine the factors that lead to customer preference of different Microfinance services, the score of women preference and the degree of respective effects was cross-tabulated to establish the total effects (negative and positive). From these scores, means and percentage proportions were used to rank the various microfinance services' effects (negative and positive) to the women economic empowerment. Generally, there is no agreement on which format is most appropriate for measuring service quality (Gupta, 2004). The concepts to be tested include self-employment, control of resources, the increment in savings and access to borrowings.

The researcher used the relationship and actual outcome among the variables to determine the impact of MFIs services on economic empowerment of women entrepreneurs using regression techniques. The association between the general objective and specific variable was very important. Yunus (2001) assessed the use of multiple regression analysis in examining credit recovery in the microfinance industry and found it likely that different models may be appropriate for different samples and research variables. Multiple regression was used to determine whether the specific variables together could predict a given research gap. The regression model that was adopted took the form of:-

$\mathrm{Y}=\alpha 0+\beta 1 \mathrm{X} 1+\beta 2 \mathrm{X} 2+\beta 3 \mathrm{X} 3+\beta 4 \mathrm{X} 4+\mathrm{E} 1$

Where,
a) $\mathrm{Y}=$ Economic Empowerment of women Entrepreneurs
b) $\alpha 0=$ Constant $=$ level of women empowerment without the microfinance services
c) $\beta 1, \beta 2, \beta 3, \beta 4,=$ the coefficients/ determinants of Economic empowerment (control of resources, self employment, access to borrowings, increased savings)
d) X1 = savings
e) $\mathrm{X} 2=$ advisory services
f) $\mathrm{X} 3=$ insurance services
g) $\mathrm{X} 4=$ microcredit services
h) E1 $=$ Error term $=$ effects due to other microfinance services e.g. asset financing.

Data was converted into a structural form suitable for regression analysis and in such a way that the software that was used in the analysis uploaded it easily. Young, (1999) notes that data summarization and visualization should involve different methods to achieve data summarization and visualization like; Tabulations, X-Y scatter plots, normal probability plots and density estimates among others. The aim is to bring about the main features of the data and to guide in choosing the appropriate statistical techniques. The process of data summarization and visualization was then appropriately linked to the concept of exploratory data analysis (EDA) whose approach and philosophy was to allow the data to dictate the process whereby SPSS (version 22) techniques of analysis that was employed to further simplify the analysis. 


\section{Research findings}

The researcher had targeted a population of 40 respondents from ten Microfinance Institutions of different nature in the Kakamega CBD, each contributing 4 active women entrepreneurs but 10 from Kenya Women Finance Trust Bank were to be attended to whose number increased to 15 in total hence the total of the targeted population came to 45 .

\subsection{Regression analysis}

The researcher stated the linear regression overall, looked at the usefulness of the model, tested and interpreted the coefficient appropriately. The table below shows the output information about the quantity of variance that is explained by the predictor variables. The first statistic, $\mathrm{R}$, is the multiple correlation coefficients between all the predictor variables and the dependent variable i.e. it measures the correlation between dependent and independent variables. In this model, the value is 0.803 , which indicates that there is a positive (+ve) co-variance shared by the independent variables and the dependent variable. The next value, $R$, square, is simply the squared value of $R$. This is the amount of variance explained by the given set of predictor variables as shown below the table. In this model, the value is 0.645 , which indicates $64.5 \%$ of the variance in the dependent variable is explained by the independent variables in the model:

$$
\mathrm{Y}=\alpha 0+\beta 1 \mathrm{X} 1+\beta 2 \mathrm{X} 2+\beta 3 \mathrm{X} 3+\beta 4 \mathrm{X} 4+\dot{\varepsilon}
$$

\section{Dependent variable Independent variables}

$\mathrm{Y}$, denotes the women entrepreneurs economic empowerment which is measured through self- employment, control of resources, savings level and access to Micro-credit facilities

a) $\alpha 0=$ Constant $=$ level of women empowerment without the microfinance services

b) $\beta 1, \beta 2, \beta 3, \beta 4,=$ the coefficients/ determinants of Economic empowerment (control of resources, selfemployment, access to borrowings, increased savings)

c) $\mathrm{X} 1=$ Savings

d) $\mathrm{X} 2=$ Advisory services

e) $\mathrm{X} 3=$ insurance services

f) $\mathrm{X} 4=$ microcredit services

g) $\dot{\varepsilon}=$ Error term $=$ effects due to other microfinance services e.g. asset financing All these variables have been measured by various parameters in the questionnaire as indicated in the operationalization framework in chapter two.

Table 4.1.1: Model Summary

\begin{tabular}{|c|c|c|c|c|c|c|c|c|c|c|}
\hline \multirow[t]{2}{*}{ Model } & \multirow[t]{2}{*}{$\mathrm{R}$} & \multirow{2}{*}{$\begin{array}{l}\mathrm{R} \\
\text { Square }\end{array}$} & \multirow{2}{*}{$\begin{array}{l}\text { Adjusted } \\
\text { R Square }\end{array}$} & Std. Error & \multicolumn{5}{|c|}{ Change Statistics } & \\
\hline & & & & Lommat & $\begin{array}{l}\mathrm{R} \text { Square } \\
\text { Change }\end{array}$ & F Change & df1 & df2 & $\begin{array}{l}\text { Sig. } \\
\text { Change }\end{array}$ & $\mathrm{F}$ \\
\hline 1 & $.803(a)$ & .645 & .621 & .633 & .645 & 21.29 & 4 & 44 & .000 & \\
\hline
\end{tabular}

Source: Research findings, 2012

(a) Predictors: (Constant), Advisory services, Insurance services, Savings and Microcredit services

(b) Dependent Variable: Economic empowerment (self-employment, control of resources, savings and access to microcredits). Adjusted R2 is called the coefficient of determination and tells us how women entrepreneurs' economic empowerment varied with Advisory services, insurance services, savings services and micro-credit services. From table 28 above, the value of adjusted R2 is 0.645 . This implies that there was a variation of $64.5 \%$ between the dependent and the independent variables. This simply means that, when advisory services, insurance services, micro-credit services and savings services are jointly applied, women entrepreneurs' economic empowerment would be achieved at $64.5 \%$. 
Table 4.1.2: ANOVAb

\begin{tabular}{|c|c|c|c|c|c|c|}
\hline Model & & $\begin{array}{l}\text { Sum } \\
\text { Squares }\end{array}$ & of $\mathrm{df}$ & Mean Square & $\mathrm{F}$ & Sig. \\
\hline \multirow[t]{3}{*}{1} & Regression & 23.7 & 4 & 5.925 & 21.29 & $.000(a)$ \\
\hline & Residual & 7.8 & 40 & 0.195 & & \\
\hline & Total & 31.5 & 44 & & & \\
\hline
\end{tabular}

Source: Research Findings, 2015

(a) Predictors: (Constant), advisory services, insurance services, savings services, micro-credit services

(b) Dependent Variable: economic empowerment

The researcher used this test to explain whether all the $\mathrm{Xi}$ (Independent variables) taken significantly explain the variability observed in the Y (Dependent Variable). In the table 29 above, the F statistic is equal to 21.29. The distribution is $\mathrm{F}(4,40)$, i.e. for 4 numerator degrees of freedom and 40 denominator degrees of freedom implies that 2.61 is the upper limit of the acceptance region for a significance level of $\alpha=0.05$. Our $\mathrm{f}$ value is 21.29 which is greater than Fcrit $=2.61$, so from this the researcher concluded that the regression as a whole is highly significant. There is strong evidence that $\beta \mathrm{i}$ is not equal to zero. Therefore, the researcher concluded from the data above that there is a linear relationship between the entire $\mathrm{Xi}$ variables considered together and y variable. And so the regression as a whole is highly significant. The researcher reached the same conclusion by noting that the output tells us that "p" is 0.000 this is the F significance value that implies an f-significance value of $\mathrm{p}<0.000$. Because this probability value is less than the significance level of $\alpha=0.05$, the researcher concluded that the regression as a whole is significant. To test this statistic the researcher used a table of $\mathrm{F}$ to determine a critical test value for a probability of 0.05 or $5 \%$ (this relationship can occur by chance only in 5 out 100 cases) and with 4, 40 degrees of freedom. According to the table the critical test value is 2.61 . In this test, the relationship is deemed significant because the calculated F-statistic is greater than the critical test value. This regression is statistically significant at the 0.05 level because is greater than 2.61 .

\subsection{Finding and interpreting the regression equation}

The table below shows the standard regression output provides information about the effects of the individual predictor variables accounted for in the model, from which the Regression model figures were derived from. It was generated to test how well the regression equation fits the data.

Table 4.2: Coefficients of regression

\begin{tabular}{|c|c|c|c|c|c|c|c|c|c|c|c|}
\hline \multirow[t]{3}{*}{$\begin{array}{l}\text { Mo- } \\
\text { del }\end{array}$} & & \multicolumn{2}{|c|}{$\begin{array}{l}\text { Unstandardized } \\
\text { Coefficients }\end{array}$} & \multirow[t]{3}{*}{$\begin{array}{l}\text { Standardized } \\
\text { Coefficients }\end{array}$} & \multirow[t]{3}{*}{$\mathrm{t}$} & \multirow[t]{3}{*}{ Sig. } & \multicolumn{4}{|c|}{$\begin{array}{l}\text { Confidence } \\
\text { Interval for } \\
\text { B }\end{array}$} & \\
\hline & & B & Std. & & & & Lower & Upper & Zero- & Partia & Part \\
\hline & & & Error & & & & Bound & Bound & order & & \\
\hline \multirow[t]{9}{*}{1} & (Constant) & .357 & .309 & & 1.155 & .123 & -.563 & 1.217 & & & \\
\hline & Insurance & .129 & .253 & .129 & 0.509 & .187 & -.117 & .321 & .433 & .174 & .08 \\
\hline & services & & & & & & & & & & 1 \\
\hline & Advisory & .613 & .231 & .298 & 2.654 & .111 & .086 & .532 & .486 & .303 & .19 \\
\hline & services & & & & & & & & & & 7 \\
\hline & Micro- & .334 & .119 & .561 & 2.812 & .233 & -.429 & .186 & .395 & .010 & .09 \\
\hline & $\begin{array}{l}\text { credit } \\
\text { services }\end{array}$ & & & & & & & & & & 2 \\
\hline & Savings & .081 & .142 & .176 & .569 & .421 & -.166 & .429 & .572 & .121 & .06 \\
\hline & services & & & & & & & & & & 8 \\
\hline
\end{tabular}

Source: Research Findings, 2015

a) Dependent Variable: Economic empowerment

From the above table our overall Regression model would now be: 


$$
\begin{gathered}
\mathrm{Y}=0.357+0.129 \text { Insurance services }+0.613 \text { advisory services }+0.334 \text { Micro-credit services }+0.081 \text { savings } \\
\text { services }+0.309
\end{gathered}
$$

The coefficients indicate the increase in the value of the dependent variable for each unit increase in the predictor variable. In this study therefore; The unstandardized coefficient for insurance services is 0.129 , which indicates that for each insurance service unit, the predicted economic empowerment increases by $12.9 \%$ given that all the other predictor variables, (Xi) are held constant for each additional unit to Insurance services.

The unstandardized coefficient for advisory services is 0.613 , which indicates that for each Recurrent advisory service unit, the predicted women entrepreneurs economic empowerment increases by $61.3 \%$ given that all the other predictor variables, (Xi) are held constant for each additional unit to the Recurrent advisory service.

The unstandardized coefficient for microcredit is 0.334 , which indicates that for each microcredit service unit, the predicted economic empowerment of women entrepreneurs increases by $33.4 \%$ given that all the other predictor variables, $(\mathrm{Xi})$ are held constant for each additional unit to the Micro-credit service.

The unstandardized coefficient for Savings services is 0.081 , which indicates that for each unit of saving service, the predicted economic empowerment of women entrepreneurs increases by $8.1 \%$ given that all the other predictor variables, $(\mathrm{Xi})$ are held constant for each additional unit to savings service.

In looking at the different unstandardized coefficients of the independent variables comparing them with each other the researcher found out that the advisory services $(61.3 \%)$ predictor was the best predictor variable followed by Microcredit service (33.4\%), then Insurance predictor (12.9\%) and lastly savings services $(8.1 \%)$

\section{Summary, Conclusion and Recommendations}

\subsection{Conclusion}

With regard to whether the MFIs services had contributed to economically empowering women entrepreneurs, the study found that there was an improvement in advisory services and savings services besides the microcredit services which have been in existence some six years ago. Therefore the MFIs have somehow improved their services offered including expounding the spectrum of services they offer apart from the traditional Microcredit services. Although the MFIs have improved their spectrum of services, they seem to stick much on the traditional services and not giving a chance to the emerging need for additional services that may assist the women entrepreneurs get more empowered economically than before.

The data indicated that there was increased women involvement in decision making, control over resources, selfemployment and increase in savings with vis-à-vis Advisory services and Microcredit services, but there was a great negation of women involvement in decision making, control over resources, self-employment and increase in savings vis-à-vis insurance services and savings services. This was further confirmed by applying the regression analysis. Nearly a half of the interviewed women said that due to the incorporation of advisory services, their standard of living had improved to some extent by enabling them meet some of their basic necessities as well as participating in decision making in their houses(increased say). Furthermore, the vast population of self-employed and controlling of resources by respondents was an indicator of increased economic empowerment of women entrepreneurs. Some women entrepreneurs undertook activities which were hitherto considered to be non-feminine.

\subsection{Recommendations}

\subsubsection{The government should:}

1. Create an enabling environment for microenterprises by making requisite financial reforms and formulating appropriate policies.

2. Carry out institutional and policy reforms to promote better access and secure rights to assets for women by ensuring more economic growth and channel more resources to women development through licensing more MFIs. 


\subsubsection{Suggestions for Further Research}

In the light of the findings discussed above the following areas are recommended for further research:

1. The impact of micro-finance services on social empowerment of women entrepreneurs.

2. The impact of microfinance services on political empowerment of women entrepreneurs

\section{References}

- Armendariz de Aghion, Beatriz and Jonathan Morduch , (2000), on Microfinance beyond group lending, Economics of Transition

- Barnes, Carolyn, Gayle Morris, and Gary Gaile, (2007), an Assessment of Client of Microfinance Programs in Uganda, International Journal of Economic Development

- $\quad$ Barret , (2005), microfinance institutions and developing countries subscriptions.

- Baydas, Mayada M., Richard L. Meyer, and Nelson Aguilera-Alfred, (2004), Discrimination against women in formal credit markets: Reality or rhetoric? World Development

- Bennett, L. and C. Cuevas, (2006), Sustainable banking with the Poor, Journal of International Development $8,145-152$

- Berger, Allen N. and Gregory F. Udell, (2001), Relationship lending and lines of credit in small firmfinance, Journal of Business 68, 351-381

- Beverly, Sondra and Michael Sherraden, (2005), Institutional determinants of savings: implications for lowincome households and public policy, Journal of Socio-Economics 28, 457-473.

- Buckley, Graeme, (2007), Microfinance in Africa: Is it either the problem or the solution? World Development 25, 1081-1093.

- Christen, Robert Peck, Elisabeth Rhyne, Robert Vogel, and Cressida McKean. (2005) "Maximizing the Outreach of Microenterprise Finance: An Analysis of Successful Microfinance Programs" USAID Program and Operations Assessment Report No. 10. Washington, D.C.: U.S. Agency for International Development

- Churchill, Craig, (2002), tries to understand the Demand for Micro insurance, Journal of International Development 14, 381-387.

- Copestake, J., Bhalotra, S., \& Johnson, S. (2001). Assessing the impact of microcredit: A Zambian case study Journal of Development Studies, 37(4), 81-100

- Copestake, James, Sonia Bhalotra, and Susan Johnson, (2007), assessing the impact of microcredit: A Zambian case study, The Journal of Development Studies 37, 81-100

- Copisarow, Rosalind, (2009), the application of microcredit technology to the UK: Key commercial and policy issues, Journal of Microfinance 2, 13-42

- Harper, Malcolm, (2007), "Promotion of Self Help Groups under the SHG Bank Linkage Program in India", Paper presented at the Seminar on SHG-bank Linkage Programme at New Delhi, November 25-26, 2002. 